\title{
BEYOND BIOLOGICAL MATERNITY: KATHERINE MANSFIELD'S AUTOBIOGRAPHICAL EXPERIENCE
}

\author{
GERARDO RODRÍGUEZ SALAS \\ University of Granada
}

\section{INTRODUCTION}

The ambiguity that characterises Katherine Mansfield's writing, fictional and non-fictional, materialises in her perception of maternity. This is one of the issues that permeated both her written narratives and her real life, and with which she endeavoured to come to terms. In her fiction, Mansfield strongly criticises biological maternity that she conceives as limiting and mutilating for women, as can be inferred from the following examples taken from her stories «A Birthday» and "Frau Brechenmacher Attends a Wedding»:

"His wife simply 'dropped' her fourth [baby]»'; "Marriage certainly changed a woman far more than it did a man. Talk about sobering down. She had lost all her go in two months! $»^{2} ;$ "[She was] the wife of a postman and the mother of five children $»^{3}$.

These images portray women as reproduction machines who have been programmed to give birth and to be burnt out in the process. Besides, their "labour» is not properly acknowledged, as they are not even granted an individual and independent status, but a subsidiary one to men and to the patriarchal system: that of "wives» (Frau or Mrs. Brechenmacher) or «mothers».

In a previous work ${ }^{4}$, I offered a detailed analysis of this writer's criticism on maternity in her fiction, a criticism that gathers conviction through her technique of "intentional mimicry». This highly effective feminist technique

1. Mansfield, Katherine: The Collected Stories of Katherine Mansfield, London, Penguin Books, 1981 (1945), p. 735.

2. Ibid., p. 742.

3. Ibid., p. 706.

4. Rodríguez Salas, Gerardo: "Mimicry' o 'masquerade': la imitación intencionada» and "La Mater Dolorosa", in La marginalidad como opción en Katherine Mansfield: postmodernismo, feminismo y relato corto, Granada, Servicio de publicaciones de la Universidad de Granada, 2004, pp. 387-391 and 421-440. 
was initially theorised by Joan Rivière in her article "Womanliness and Masquerade ${ }^{5}$, and later by Mary Ann Doane ${ }^{6}$ or Luce Irigaray ${ }^{7}$. Catherine Porter explains this intentional mimicry or masquerade:

"An interim strategy for dealing with the realm of discourse (where the speaking subject is posited as masculine), in which the woman deliberately assumes the feminine style and posture assigned to her within this discourse in order to uncover the mechanisms by which it exploits her».

It is, therefore, an original and ironic weapon that allows women to consciously reproduce traditional gender roles (or «femininity») that patriarchal models have tailored for them since long ago; thus, they adopt an apparently innocent and infantile position, but their imitation is intentional and subversive.

The two main feminine gender roles that Mansfield parodies in her stories are the rebel woman (dramatised in the three stereotypes of the New Woman, the lesbian and the femme fatale) and the mother (reflected in the "Angel in the House» and, to a lesser extent, in the rebellious mother $)^{9}$. Although the focus of this study will be the mother figure, the rebel woman will also be important in order to understand Mansfield's complex attitude towards maternity in her autobiographical experience. While in her fiction she successfully implements the conscious mimicry of biological maternity, in her real life (as can be inferred from her autobiographical material) she faced this issue with attitudes of greater complexity. She resorted to a metaphorical maternal figure that compensated for her sterility and covered the emotional gap that her husband, John Middleton Murry, could not fill. The study of her journal and letters as regards her ambiguous motherhood will be the topic of the present article.

\section{DE BEAUVOIR AND KRISTEVA ON MATERNITY}

To understand Mansfield's reaction against biological maternity in fiction and real life, we have to start theorising the negativity that has traditionally surrounded images of women. The writer's intention is to show that, not only the minds of men are full of negative representations of women, but women themselves have internalised these images and accepted them without further questioning. This feminine pessimism emerges as the negative equivalent to the figure of man and the traditional values attributed to him. Thus, Jacqueline Rose states that:

5. Rivière, Joan: «Womanliness As a Masquerade», in Athol Hughes (ed.): The Inner World and Joan Rivière. Collected Papers: 1920-1958, London and New York, Karnac Books, 1991 (1929), p. 95.

6. Doane, Mary Ann: Femmes Fatales: Feminism, Film Theory, Psychoanalysis, New York and London, Routledge, 1991, p. 25.

7. IrigaraY, Luce: "The Power of Discourse and the Subordination of the Feminine: Interview», in Catherine Porter (trans.): This Sex Which is Not One, New York, Cornell University Press, 1996a (1985), p. 78; "Così Fan Tutti», in Ibid., p. 101.

8. Porter, Catherine: «Publisher's Note and Notes on Selected Terms», in Ibid., p. 200.

9. For a detailed analysis of these two stereotypes in Mansfield's fiction, see Rodríguez SaLAS, Gerardo: Op. Cit., pp. 399-440. 
"[t] he woman, therefore, is not, because she is defined purely against the man (she is the negative of that definition - 'man is not woman')» ${ }^{10}$.

In turn, Simone de Beauvoir offers her theory of woman as "the Other», as she is not considered

"positively, such as she seems to herself to be, but negatively, such as she appears to man. For if woman is not the only Other, it remains none the less true that she is always defined as the Other. And her ambiguity is just that of the concept of the Other: it is that of the human situation in so far as it is defined in its relation with the Other. As I have already said, the Other is Evil; but being necessary to the Good, it turns into the Good»11.

Although de Beauvoir states that women see themselves positively, once they have internalised the negative perception that patriarchy has about them, they never manage to view themselves fully favourably again. A rooted guilt complex will be the result if they pursue their own desire and try to escape from the restrictive image they have been forced to internalise and carry.

Consequently, this vision of women leads to the appearance of a series of negative feminine myths within patriarchal society, initially defined by de Beauvoir, and later summarised by Julia Kristeva in her articles "About Chinese Women» and "Stabat Mater». Kristeva polarises these limiting stereotypes for women: Virgin Mary and Eve, the first woman ${ }^{12}$. Thus, she reminds us that, according to patriarchal convention, the former is associated with the life and purity of the dove, while the latter is linked with the death and corruption of the snake. In turn, using a traditional terminology, $\mathrm{M}^{\mathrm{a}}$ del Mar Pérez Gil cites two other images that imply the same dichotomy: the "Angel in the House», that is, the woman confined at home who has to take care of her family and preserve her purity, and the "demon", or the woman who is expelled from society because she has flouted the rules that limit her, and whose association with the snake of the Bible is evident ${ }^{13}$. This binarism, regardless of the labels we use, summarises traditional feminine iconography and restricts the freedom of women by locating them obligatorily within one category or another. Of course, the "Angel in the House» is supported by the system, while the rebel woman is ostracised for life.

As regards the stereotype of the dependent woman, Kristeva associates it with the icon of the Virgin Mary that she considers as "one of the most powerful imaginary constructs known in the history of civilizations» ${ }^{14}$ and calls

10. Rose, Jacqueline: "Introduction II», in Juliet Mitchell and Jacqueline Rose (ed.) and Jacqueline Rose (trans.): Feminine Sexuality: Jacques Lacan and the École Freudienne, Basingstoke, MacMillan, 1982, p. 49.

11. De Beauvorr, Simone: H.M. Parshley (ed. and trans.): The Second Sex, Middlesex, Penguin Books, 1984 (1979), p. 175.

12. KristeVA, Julia: «Stabat Mater», in Toril Moi (ed.) and León S. Roudiez (trans.): The Kristeva Reader, Oxford, Basil Blackwell, 1986a (1977), pp. 165-166.

13. Pérez Gil, Ma del Mar: La subversión del poder en Angela Carter, Las Palmas de Gran Canaria, Servicio de Publicaciones, 1996, p. 60.

14. Kristeva, Julia: «Stabat Mater», op. cit., p. 163. 
"the biblical woman", who will be "wife, daughter or sister, or all of them at once» ${ }^{15}$. Echoing the Church, she describes her as:

«mother of her son and his daughter as well [...] and besides his wife: she therefore actualizes the threefold metamorphosis of a woman in the tightest parenthood structure $»^{16}$.

As the prototype of woman who has to be imitated by the rest according to the monolithic Christian-patriarchal model, Virgin Mary stands for the sacrificed image, subdued to men's superiority. Later, this Marian cult of medieval times, which Marina Warner traces back to the late eleventh century reaching its zenith in the fourteenth, was progressively secularised until it gave way to the image of the "Angel in the House ${ }^{17}$. extended all over the AngloSaxon world with the poem of that title by Coventry Patmore (1854-1863). This icon established itself strongly within Victorian Puritanism, even surviving the dramatic social changes of the twentieth century.

In the case of these two intertwined images, the Virgin and the "Angel in the House", as Kristeva states ${ }^{18}$, their function is to assure procreation and, therefore, the continuation of patriarchal omnipresence. This explains their positive presentation and their association with life, since they represent feminine maternity and virginity, turning into universal icons with which all women might identify. As Margaret Bruzelius points out ${ }^{19}$, married women who have a family identify themselves with the maternal side, while conservative single women feel closer to the purity of the virgin. Thus, this double figure is the most limiting of them all. Focusing on the myth of maternity, Ann Oakley summarises the three traditional patriarchal reasons to keep it: children need their mothers, mothers need their children and maternity stands for the big achievement in women's lives and the only means of self-fulfilment ${ }^{20}$.

The deconstructive process of this image started with such authors as de Beauvoir. For her, maternity has to be rejected, since it leads to the mutilation of feminine agency. She defines pregnancy as:

«a drama that is acted out without the woman herself. She feels at once an enrichment and an injury; the foetus is a part of her body, and it is a parasite that feeds on it; she possesses it, and she is possessed by it $\rangle^{21}$.

The baby becomes then a burden that annihilates the mother. Besides, she adds that maternity is the only female function almost impossible to fulfil in

15. KristeVA, Julia: "About Chinese Women», in Toril Moi (ed.) and Seán Hand (trans.): The Kristeva Reader, Oxford, Basil Blackwell, 1986b (1974), p. 140.

16. KRISTEVA, Julia: «Stabat Mater», op. cit., p. 169.

17. Warner, Marina: "Mater Dolorosa», in Alone of All Her Sex: The Myth and Cult of the Virgin Mary, London, Vintage, 1976, p. 210.

18. KristeVA, Julia: "About Chinese Women», op. cit., p. 140.

19. BruzeLius, Margaret: "Mother's Pain, Mother's Voice: Gabriela Mistral, Julia Kristeva, and the Mater Dolorosa", Tulsa Studies in Women's Literature, 18.2 (1999), pp. 220-221.

20. Oakley, Ann: Housewife, London, Allen Lane Penguin Books, 1974, p. 186.

21. De Beauvoir, Simone: Op. cit., p. 512. 
complete freedom ${ }^{22}$. Therefore, she suggests the poisonous effect of maternity for women and claims for its rejection in order to enter the masculine sphere, an opinion that is softened by other critics like Kristeva, who carries out a deconstruction of maternity without refuting it.

Kristeva starts acknowledging the annihilating origins of the concept of the Mater Dolorosa, or the woman who blindly accepts her maternity. In her article "Stabat Mater» she alludes to this figure that, as Toril Moi clarifies in her introduction to Kristeva's article, derives from a Latin hymn about Virgin Mary's agony at her son's crucifixion. This song starts with the words «[s]tabat mater dolorosa [...]»; that is, "stood the mournful Mother». In her study on the Virgin, particularly on Chapter 14, Warner considers that the myth joins in the medieval conception of life as a valley of tears and sacrifice for which we will be rewarded in a future life ${ }^{23}$. In Warner's opinion, the real intention behind this social construct is to keep women at the service of patriarchy. The negative consequences for them, as Bruzelius states, can even be perceived nowadays:

«It is depressing to note that the identification of motherhood with suffering and the validation of the maternal voice through that suffering, which has been so effectively fostered by the church in the case of Mary, continues almost unquestioned today ${ }^{24}$.

The negativity of this image fabricated by one of the most powerful institutions of patriarchy, the Church, is equally acknowledged by Kristeva, when she associates it with the concept of «femininity» that, for her, is an empty signifier ${ }^{25}$ or, as Luce Irigaray explains:

«a role, an image, a value, imposed upon women by male systems of representation. In this masquerade of femininity, the woman loses herself, and loses herself by playing on her femininity ${ }^{26}$.

Kristeva speaks of an absorption of femininity by the maternal, which is common to many civilisations, although it reaches its climax in Christianity. At this point, Kristeva wonders whether such a reduction is no more than a masculine appropriation of maternity in line with the phantasmagoric reality of femininity that has been theorised by the critics above ${ }^{27}$. In this sense,

22. Ibid., p. 705.

23. Warner, Marina: Op. cit.

24. Bruzelius, Margaret: Op. cit., p. 215.

25. KristeVA, Julia: «Talking about Polylogue», in Toril Moi (ed.): French Feminist Thought: A Reader, New York, Basil Blackwell, 1989, p. 114.

26. IrIgARAY, Luce: "The Power of Discourse and the Subordination of the Feminine: Interview», op. cit., p. 84. Other critics who view femininity as a mask that hides a void are Joan Riviére (op. cit., p. 95), Toril Moi ("Feminist Literary Criticism», in Ann Jefferson and David Robey (eds.): Modern Literary Theory: A Comparative Introduction, London, B.T. Batsford, 1993 (1982), p. 219), Mary Ann Doane (op. cit., pp. 25, 31) or M. Alison Arnett («A Metaphor of the Unspoken: Kristeva's Semiotic Chora", in Hugh J. Silverman (ed.): Continental Philosophy VI. Cultural Semiosis: Tracing the Signifier, New York and London, Routledge, 1998, p. 165).

27. KRISTEVA, Julia: «Stabat Mater», op. cit., p. 163. 
motherhood participates in the artificiality of the "feminine», being both maternity and femininity a patriarchal construction with an appearance of reality, since women adopt these roles, although they are but a pure fantasy that authors like Kristeva endeavour to dismantle.

Illustrating Kristeva's theory on maternity, Bruzelius refers to the "personal emptiness» of Virgin Mary, and concludes that motherhood involves a "catastrophe» of identity associated with femininity, the absence of language and body ${ }^{28}$. The result of patriarchal control on the mother figure is the distinction between "pleasure» and "jouissance», which Charles Shepherdson links with "the maternal» and "the imaginary", respectively ${ }^{29}$; that is, "jouissance» implies a destructive drive that leads to feminine hysteria and the disobedient figure of the femme fatale, while "pleasure» involves the mediation of the runaway force of the jouissance through the symbolic order of patriarchy, which ends up limiting feminine expectations to avoid a female rebellion against the system.

However, despite recognising the mutilation of this feminine image, Kristeva does not reject it, as did de Beauvoir, but she claims for its reuse with a feminist goal. This is what she says in her article "Women's Time»:

"To desire to be a mother, considered alienating and even reactionary by the preceding generation of feminists, has obviously not become a standard for the present generation. But we have seen in the past few years an increasing number of women who not only consider their maternity compatible with their professional life or their feminist involvement [...], but also find it indispensable to their discovery, not of the plenitude, but of the complexity of the female experience, with all that this complexity comprises in joy and pain ${ }^{30}$.

It is, thus, a matter of finding in maternity the complexity that characterises the semiotic order (that before entering the rationality of language and patriarchy), and not the restriction that imposes the symbolic order. As Ewa Plonowska Ziarek states:

«any attempt to transform the maternal body into a coherent signifying position is a fraud, precisely because it is a heterogeneous site, constantly doubling itself and separating itself from itself. The maternal body, then, becomes a nonsite, an impurity and a distance encroaching on the positionality of the symbolic language ${ }^{31}$.

This is precisely what Kristeva advocates: to replace the loss of maternity and femininity with a variety that provides women with an endless range of possibilities. This study agrees with Eluned Summers-Bremner in stating that

28. Bruzelius, Margater: op. cit., pp. 226 and 228.

29. Shepherdson, Charles: Vital Signs: Nature, Culture, Psychoanalysis, New York and London, Routledge, 2000, pp. 71-72.

30. KristeVA, Julia: «Women's Time», in Toril Moi (ed.) and Alice Jardine and Harry Blake (trans.): The Kristeva Reader, Oxford, Basil Blackwell, 1986c (1979), p. 205.

31. ZiareK, Ewa Plonowska: «At The Limits of Discourse: Heterogeneity, Alterity, and the Maternal Body in Kristeva's Thought», in Christina Hendricks and Kelly Oliver (eds.): Language and Liberation. Feminism, Philosophy, and Language, Albany, New York, State University of New York Press, 1999, p. 334. 
Kristeva usurps the Virgin as the agent that carries out transgression in her text; she deconstructs her passivity and negativity and reuses her as a receptacle of multiplicity and a vehicle that unchains a revolutionary process ${ }^{32}$. Thus, she endows the mother with a new signification and life, as can be seen in her essay "Stabat Mater». While the figures of the maternal and intellectual woman have always been perceived as contradictory and irreconcilable, in this article Kristeva makes them coexist to defend the multiplicity of the feminine position, as opposed to the patriarchal restriction of it. She divides the text into two columns: the left one, in bold type, is the maternal discourse, irrational and chaotic; the right one is the academic and intellectual speech. The last one predominates in the text, which is not surprising if we consider that, for Kristeva, the organising principle of the symbolic order is necessary for women to gain a voice in the patriarchal system and to prevent the uncontrolled force of the semiotic order that could lead to hysteria. At least, she offers an alternative: the possibility to read the dominant and/or the marginal/semiotic discourse at the same time. Her greatest achievement will be to revitalise the maternal image and to use it with subversive aims through what SummersBremner calls «subversive imitation $»^{33}$.

Therefore, we can say that all possible feminine roles for women are restrictive. The images of the Mater Dolorosa and the femme fatale are intertwined, and together they represent their own tragedy. The first one is no more than a social mask, since the woman pretends to be immaculate, but a powerful desire that cannot be ignored grows inside her. However, if she allows it to come outside, she becomes the femme fatale and the most negative connotations are attributed to her. There does not seem to exist here any hope for women. The only possible alternatives are to reuse these images with a parodying and strategic intention, inverting them in front of the readers' eyes so that a process of gradual awareness and future real revolution might take place, or to try to attain a synthesis of these two opposing images to give birth to a functional approach to living for flesh and bone women, who may then adopt a type of maternity that is not deadly for them.

Mansfield develops the first alternative in her fiction; she applies the second one to her autobiographical experience, and that is the focus of this article.

\section{METAPHORICAL MATERNITY: MANSFIELD'S JOURNAL AND LETTERS}

According to Patricia Moran ${ }^{34}$, Mansfield resented the mother figure, which she considered as asphyxiating in its symbiotic fusion with the baby before its entry into the symbolic order. In Moran's opinion, this writer shows a "matrophobia", or fear of becoming a mother, and all that it implies. Mansfield

32. Summers-Bremner, Eluned: "Hysterical Visions: Kristeva and Irigaray on the Virgin Mary», Women: A Cultural Review, 9.2 (1998), p. 187.

33. Ibid., p. 184.

34. Moran, Patricia: «Unholy Meanings: Maternity, Creativity, and Orality in Katherine Mansfield», Feminist Studies, 17.1 (1991), p. 121. 
never solved this conflict with maternity. Such critics as Cherry A. Hankin state that Mansfield, like her female parent, identified herself with «the unwilling mother", displaying a rejection of pregnancy and childbirth that led her to a rebellion against the biological imperative in women ${ }^{35}$; the opinion of this article, however, is that she never rejected completely the concept of maternity.

It is true that, from the beginning, Mansfield identified herself with her mother, Annie Burnell Beauchamp, to whom she attributed certain reticence towards the traditional maternal figure. Thus, recollecting the birth of her younger sister Gwen, who died soon after, Mansfield describes her mother's coldness with her daughters: "mother did not want to kiss me»" ${ }^{36}$, and draws again this reluctant matriarch in stories like "Prelude» and "At the Bay» in the character of Linda Burnell, who, in turn, preserves the same surname as Mansfield's mother. Both in real life and in fiction (e.g. "Prelude» and "At the Bay»), the grandmother played the maternal role. Nevertheless, despite exposing her mother's style of maternity, the author felt very close to her on several occasions ("you and I are curiously near to each other» ${ }^{37}$ ), especially after her death:

«My little mother, my star, my courage, my own. I seem to dwell in her now. We live in the same world» (Journal: 154); "I simply cannot bear the thought that I shall not see her again $»^{38}$.

Although the relationship between them was turbulent while they lived, to the extent that Annie ended up disinheriting her daughter, maybe Mansfield experienced this closeness to her precisely because of their similar personalities.

In any case, Mansfield's position towards marriage and maternity, the same as Annie's, was ambiguous. In spite of showing an utter fear for maternity and its consequences, the writer's desire to become a mother and to fulfil the typical role of a happily married woman was manifest in the course of her life. While her adventures as an adolescent girl were bohemian and risky, after meeting Murry her wish to marry and to form a family in the purest patriarchal style grew:

«I wish I lived on a barge, with Jack for a husband and a little boy for a son»"

Besides, although being, in much of her writing, quite critical of marriage, which she perceives as poisonous for both men and women, in one of her letters she admits:

35. Hankin, Cherry A.: Katherine Mansfield and her Confessional Stories, London and Basingstoke, MacMillan, 1983, p. 190.

36. Mansfield, Katherine: John Middleton Murry (ed.): The Journal of Katherine Mansfield (Definitive Edition), London, Constable, 1954, p. 101.

37. Mansfield, Katherine: Vincent O'Sullivan and Margaret Scott (eds.): The Collected Letters of Katherine Mansfield, v.1 (1903-17), Oxford, Clarendon Press, 1984, p. 144.

38. Mansfield, Katherine: Vincent O'Sullivan and Margaret Scott (eds.): The Collected Letters of Katherine Mansfield, v.2 (1918-19), Oxford, Clarendon Press, 1987, p. 266.

39. Mansfield, Katherine: Journal, op. cit., p 58. 
"I believe in marriage. It seems to me the only possible relation that really is satisfying ${ }^{40}$.

However, her wishes never came true: Mansfield strongly desired to have a traditional family, but nothing turned out right, and she examined and developed the concept within the theatre of her narratives. After her miscarriage in Germany and suffering from venereal disease, she became sterile and tried to supply her absence of real offspring with several alternatives, such as her Japanese porcelain doll, Ribni, which she considered as her daughter ${ }^{41}$, her cats Charlie and Wingley, her failed experiment to adopt a child, which she verbalised in one of her letters to Murry ${ }^{42}$, or the consideration of the children of her own fiction as her sons, this being the case of the protagonists of the story "Sun and Moon», whom she called "my babies»" She also considered herself as the "mother» of her brother Leslie, as Christine Darrohn states ${ }^{44}$, not only after his death and subsequent recreation in her fiction, but also when she was only twenty years old ( II feel so maternal towards him» ${ }^{45}$ ), the same as with Murry's brother, Richard ${ }^{46}$, who was like a brother to her, perhaps a substitute for her dead brother Leslie ${ }^{47}$. Even with her partners, Mansfield could not help but show her protective and maternal instinct (with Garnett Trowelli8, and with Murry ${ }^{49}$ ). With them, she replaced biological maternity that she never saw fulfilled.

With respect to the idea of a perfect husband, she also deceived herself with Murry and created an idyllic image of him that she had to accept as a failure with the passage of time. Her relationship with Murry was based on the fact that both kept an eternal infantile innocence and acted like children in a fantastic world of fairy tale. Thus, on several occasions she confesses to Murry:

"You and I don't live like grown up people» ${ }^{50}$; "we are two shining children» ${ }^{51}$,

and she even calls Murry "little father» ${ }^{52}$ in her desire to share with him a kind of fictional family structure. However, she soon wakes up from her

40. Mansfield, Katherine: Vincent O'Sullivan and Margaret Scott (eds.): The Collected Letters of Katherine MANSFIELD, v.4 (1920-21), Oxford, Clarendon Press, 1996, p. 284.

41. Mansfield, Katherine: The Collected Letters, v. 2, op. cit., p. 107.

42. Mansfield, Katherine: Vincent O'Sullivan and Margaret Scott (eds.): The Collected Letters of Katherine MANSFIELD, v.3 (1919-20), Oxford, Clarendon Press, 1993, p. 133.

43. Mansfield, Katherine: The Collected Letters, v. 2, op. cit., p. 74.

44. Darrohn, Christine: “'Blown to Bits!': Katherine Mansfield's 'The Garden-Party” and The Great War», Modern Fiction Studies, 44.3 (1998), p. 517.

45. Mansfield, Katherine: The Collected Letters, v. 1, op. cit., p. 41.

46. MANSFiELD called Murry's brother Richard, although his real name was Arthur.

47. Mansfield, Katherine: The Collected Letters. v. 4, op. cit., p. 164.

48. Mansfield, Katherine: The Collected Letters, v. 1, op. cit., p. 81.

49. Mansfield, Katherine: The Collected Letters, v. 2, op. cit., p. 41.

50. Mansfield, Katherine: The Collected Letters, v. 1, op. cit., p. 255.

51. Ibid., p. 355.

52. MAnsfield, Katherine: The Collected Letters, v. 2, op. cit., p. 153. 
dream to discover that she is living an actual nightmare, since reality is quite different:

«[Murry] ought not to have married. There never was a creature less fitted by nature for life with a woman» ${ }^{53}$.

On several times, she displays her disappointment and sees herself as an «unreal» wife, encouraging Murry to "truly» marry someone who can give him real children when she dies (she thinks of Dorothy Brett ${ }^{54}$ ).

Finally, in her wish to fulfil the role of a mother and a wife, she dreams with Murry about finding an idyllic home that fits their impossible dream. They call this place "the Heron» and, later, "Broomies», when Murry buys a cottage in Marsh Common, Chailey, Sussex in 1920. Mansfield defines the "Heron» with the following words:

"It is the fortress and the hiding place of our love - the 'solid symbol'... Heavens!

What would the world think if they looked through a little glass door into my head - and saw what sweete madnesse did afflict my brayne „55.

This description suggests a medieval castle isolated from the world, where she and Murry are "children of the Heron». Mansfield is aware of her "madnesse», when she reproduces this quote of Spenser, and of her idealism, anticipating her feeling of being deceived when she comes up against reality. In fact, as she is becoming disenchanted with Murry and their false dream, she replaces this idyllic Heron with a real house where she spends her time working on her own without Murry, at Villa Isola Bella (Menton, France). At the beginning, still reluctant to awake from her chimera, she wants to see this place as the Heron of which both dreamt:

"My feeling for this little house is that somehow it ought to be ours. It is I think a perfect house ${ }^{56}$.

Later, however, she starts to see reality and conceives this little cottage as her home, when she begins to build her own realistic dream as opposed to the common one with her husband:

"Its the first real home of my own I have ever loved ${ }^{57}$.

At this point, Mansfield works out a new projection for her dream of maternity, as she substitutes the unreal and devious maternity of her biological and social plans with Murry with a metaphorical one: her labour as an artist. Hence, through her narrative and without the need to resort to the masculine element (her husband), she gives birth to her own children who bring her

53. Mansfield, Katherine: Journal, op. cit., p. 166.

54. Ibid., p. 148; MAnsfield, Katherine: The Collected Letters, v. 2, op. cit., p. 356; MANSField, Katherine:

The Collected Letters, v. 3, op. cit., p. 236.

55. Mansfield, Katherine: The Collected Letters, v. 2, op. cit., p. 117.

56. Mansfield, Katherine: The Collected Letters, v. 4, op. cit., p. 43.

57. Ibid., p. 106. 
a satisfaction, if not total, at least superior to that experienced with the misguided dream she shared with Murry. With her writing, she brings her brother, mother and children ("Sun and Moon») back to life, allowing her to create with no boundaries everything she could not have during her existence in the real world. Therefore, with respect to her work, she asserts:

"It takes the place of religion - it is religion - of people - I create my people: of 'life' - it is Life. The temptation is to kneel before it, to adore, to prostrate myself, to stay too long in a state of ecstasy before the idea of it $»^{58}$.

She sees herself as a goddess of creative fertility, who can create life and is totally satisfied with her art, a satisfaction that she never manager to express in her relation with Murry:

"If I had done my work Id even go so far as to die. I mean to jolly well keep alive with the flag flying until there is a modest shelf of books with K.M. backs. ${ }^{59}$

\section{CONCLUSION}

Mansfield seems to find the solution to the dichotomy mother/writer in her narrative maternity. In the same way that Kristeva combines both discourses in her essay "Stabat Mater» and suggests their coalescence, Mansfield finds the solution in writing, which lets women fulfil themselves professionally and, at the same time, lets them exercise their mother maternal labour in the production of endless lives in their stories. Of course, this "artificial» maternity never satisfied the author completely, but, in her fiction, biological maternity is much more devastating for women, since, as in the examples with which this article opens, they are condemned to endless procreation and the performance of domestic tasks that confine them forever in a frustrating role. The metaphorical maternity that Mansfield claims in her own figure as a real woman makes a sensible combination of the two limiting stereotypes for women that were mentioned before: the rebel woman, in that it allows this artificial mother the necessary freedom to write and perform a professional activity, and the Angel in the House with its maternal connotation, in that she has access to a family through the creation of endless lives. Of course, this metaphorical maternity is not as fulfilling as giving birth to children of flesh and bone, but it provides for a freedom and an eternity that can be more nourishing for a woman like Mansfield, who was prone to continuous dissatisfaction with her everyday life and was forced by her sterility to remain childless.

58. Mansfield, Katherine: Journal, op. cit., p. 161.

59. Mansfield, Katherine: The Collected Letters, v. 4, op. cit., p. 147. 